\title{
Chapter 11 \\ Housing Markets in Scandinavia: Supply, \\ Demand and Regulation
}

\author{
Kjersti Næss Torstensen and Kasper Roszbach
}

This chapter discusses the recent developments in the housing markets of Scandinavian capital cities and some of the policy challenges these developments are bringing about. ${ }^{1}$ First, we will briefly review some demographic trends, both over the past 10 years and looking ahead. Next, we will show some statistics on the buildup of housing supply shortages and what has happened to the price of housing. Then, drawing on a few recent housing market studies, we will go over the observed and likely consequences of housing shortages and house prices rises. Finally, we will discuss the geographical mortgage policy that was implemented in Norway, with a particular focus on restricting mortgage lending in Oslo a year ago. We conclude with a few takeaways.

\footnotetext{
This text is based on a presentation Kasper Roszbach gave at the seminar on "Hot Property: the housing market in major cities" held at De Nederlandsche Bank on May 24-25, 2018. The views expressed in this chapter are those of the authors and do not necessarily reflect those of Norges Bank or the Executive Board of Sveriges Riksbank.

${ }^{1}$ Because it is hard to get uniform statistics across all dimensions of housing markets in Scandinavia, we will discuss data for single countries and generalize these to other Scandinavian cities, while being aware of the limitations of the data. We will, very selectively and in a non-random way, draw on a number of reports and sources that have investigated the housing market in mostly Norway, Sweden and Iceland.
}

K. N. Torstensen

Norges Bank, Oslo, Norway

K. Roszbach (四)

Norges Bank, Oslo, Norway

University of Groningen, Groningen, Netherlands

e-mail: Kasper.Roszbach@ Norges-Bank.no

R. Nijskens et al. (eds.), Hot Property, https://doi.org/10.1007/978-3-030-11674-3_11 


\section{Background}

Over the past 10 years, several Scandinavian capital regions have experienced a period of rapid growth. Stockholm's population grew by about $16 \%$ while Oslo grew at an even faster rate of close to $19 \%$. Although neither of these cities belongs to the group of European cities that have grown most in absolute terms, like Paris, Madrid and Rome, the rapid growth rate of these metropolitan areas and the intensity of the resulting frictions in housing markets pose particular challenges, that we believe provide generally useful insights into the challenges that cities are confronted with in the face of rapid expansion.

Metropolitan area population growth in Scandinavia is projected by the European Commission to continue being robust. Eurostat projections, plotted in Fig. 11.1, suggest that the Stockholm metropolitan area will grow by close to $50 \%$ in the next 30 years, while Oslo will grow by more than $55 \%$. At the same time some other metropolitan areas in southern and eastern Europe are projected to shrink, while for example Amsterdam finds itself in an intermediate position. While projections do not account for substantial changes that may take place in confounding living conditions, like reduced affordability due to housing scarcity or severely lagging infrastructure, they do provide an indication of the challenges these cities may come to face.

Since 2005, the metropolitan area of Stockholm has built up a substantial housing deficit as the net annual migration rate has been hovering between 10,000 and 20,000 households while construction of new houses and apartments has been ranging from 7000 to 14,000 units (see Katinic (2018) and Fig. 11.2). The migration to Stockholm has several drivers. Among other things, there is a tendency to migrate domestically, away from rural areas. At the national level, Scandinavia and in particular Sweden, has experienced a large inflow of refugees. Net immigration in Sweden was over 100,000 in 2016 , about $1 \%$ of the ten million population. Oslo's

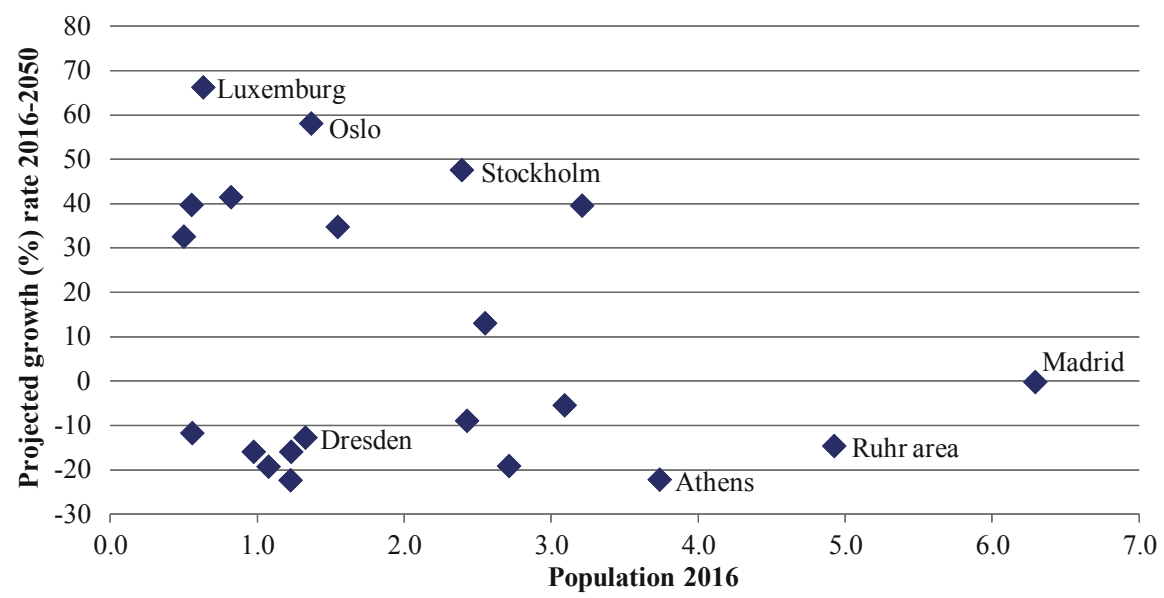

Source: European Commission (2015)

Fig. 11.1 Projected population growth rates metropolitan areas 2016-2050 


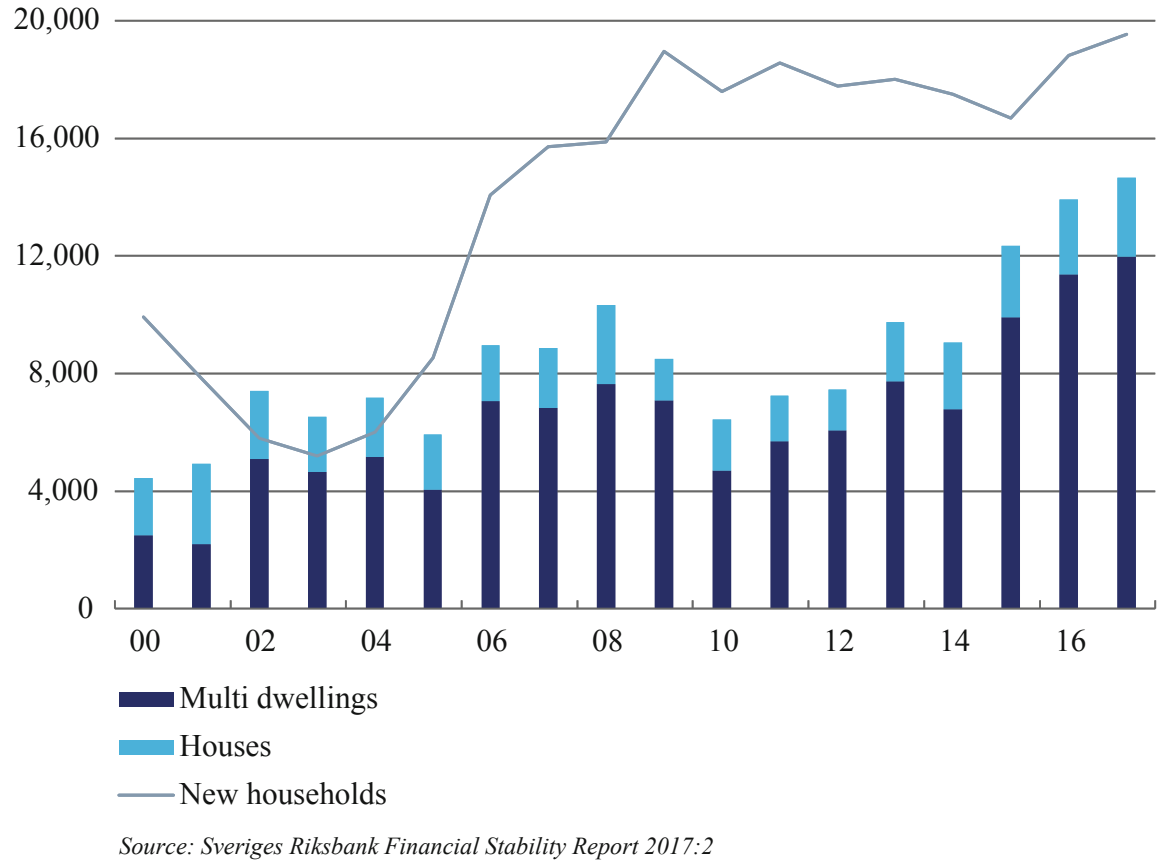

Fig. 11.2 Housing construction versus population growth in Stockholm

metropolitan area has also experienced a housing construction deficit in the period 2006-2016, although not as dramatic as Stockholm. There are some intuitively appealing explanations for this difference, which we will discuss in the next section.

The shortage of new housing has had its effect on house prices. Although Oslo and Stockholm recently experienced moderate drops in house prices, both cities saw house prices more than double in 12 years. Over the same period inner city Stockholm apartments almost tripled in price and rose by approximately $50 \%$ more than the country average (including Stockholm itself). Generally, price developments in metropolitan areas, with predominantly multifamily dwellings, can differ substantially from more rural areas with mostly single-family houses. Differences in subletting regulations, as in Sweden where single family house subletting essentially is unregulated while apartment subletting is highly restricted, have kept up the supply of single-family houses. This has exerted a dampening effect on price developments outside metropolitan areas.

In Oslo the corresponding rise in house prices has been a little more muted with a $150 \%$ increase and a slightly smaller differential vis-à-vis the rest of the country. The latter can partially be explained by the fact that oil is an important driver of the economy and thereby house prices on the west coast of Norway. Figure 11.3 illustrates how west-coast Stavanger experienced a drop in house prices when oil prices sharply fell in 2015 and 2016, while the rest of the country and was much less affected. In the past year, with oil prices recovering, house prices in Stavanger have started to recover. 


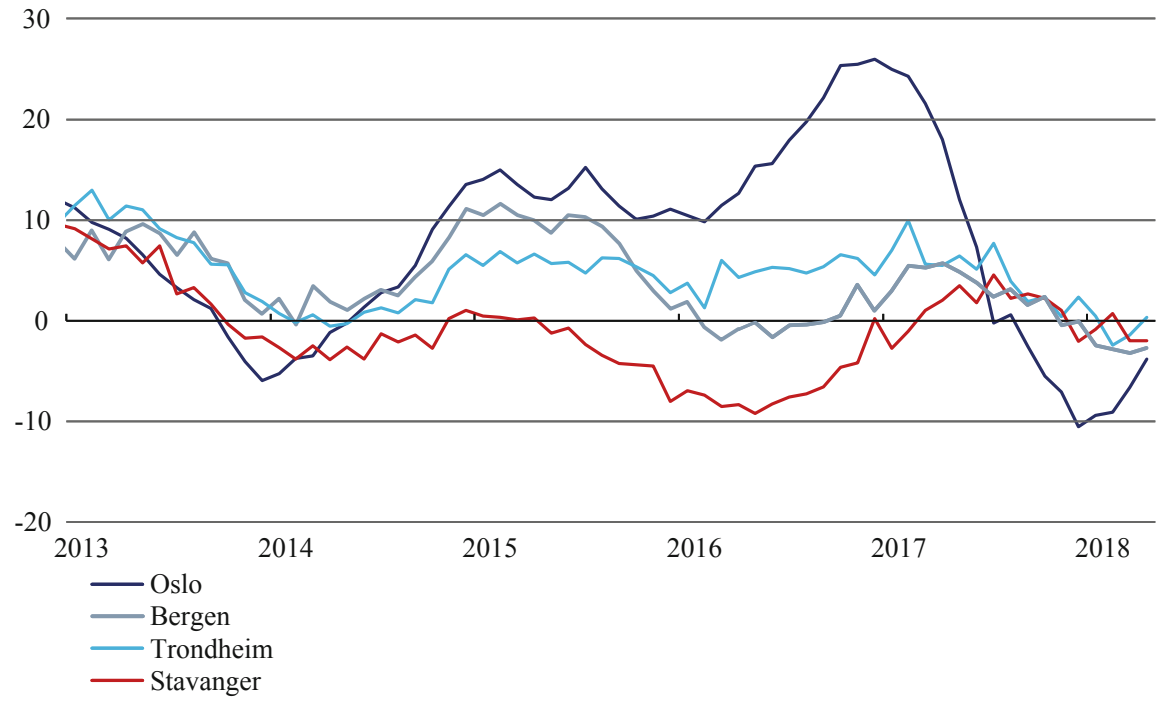

Sources: Norges Bank Financial Stability Report 2017, updated using data from Eiendomsverdi AS, www. finn.no and Real Estate Norway

Fig. 11.3 House price changes in metropolitan areas in Norway

To what extent and how rapidly the supply of housing responds to price fluctuations will among other things depend on the financial incentives produced by local housing regulations. Norway, for example, effectively has had no rent control since 2000 and experienced that new housing starts closely tracked house prices changes with a lag of up to a year. ${ }^{2}$

\section{Explanations for the Shortage and Rise in Prices of Housing}

There are a number of plausible explanations for the combination of sharply rising demand and a lagging supply of new houses in Oslo and Stockholm. In particular Stockholm has faced a shortage of land for housing construction, despite the ample availability land in the proximity of Stockholm.

\footnotetext{
${ }^{2}$ The Norwegian Tenancy Act of 1999 makes it possible for landlords, every third year, to mark up the rent to an existing rent level of comparable objects-to a "fair" rent. The last part of the old rent control was removed in 2010, affecting a small number of pre-World-War-II blocks of apartments in Oslo and Trondheim. The act restricts price increases in ongoing tenancy agreements. Rent increases on a yearly basis cannot exceed the increase in the Consumer Price Index (CPI). See Nygaard (2013) for details.
} 
In Sweden, a recent Official Government Report (2015), the "Long-Term Survey of the Swedish Economy", identifies rigid planning processes, building restrictions, for example noise standards that place certain locations off limits for housing construction, and building permit appeal procedures as important hurdles for more rapid house construction. Another friction negatively affecting housing construction is the mismatch between the budgetary and political responsibility for major infrastructure investments (central government and provinces) and the planning authority for housing construction (municipalities).

Rental regulations are also keeping rents on rent controlled apartments low, which is severely restricting the turnover of apartments because the subsidies disincentivize people to move to self-owned homes. The same government report observed that while it is common in many countries for people living in rental apartments or rental homes to be more flexible on the labor market, Swedes in selfowned dwellings are actually more mobile than those living in rentals.

On the demand side, a few non-negligible policy changes have spurred housing demand: In 2007 the wealth tax was abolished while the real estate tax was capped at approximately 600 euro per year in 2008. Instead, the capital gains taxes were raised from 20 to $22 \%$. The real estate tax had become a highly unpopular tax after several elderly people had been forced to leave their houses when they couldn't generate the cashflow to pay the annual tax, although they had substantial assets. The first two tax reforms freed up assets for housing purchases while the wealth tax abolishment also made it easier for family members to support each other in entering the housing market. The increase in the capital gains tax, in an environment with steep increases in house prices, has likely made people less inclined to move, in particular after the introduction of the LTV requirement which made cash at hand more valuable.

Simultaneously several other, secondary, factors are likely to have been at work in Scandinavia. Tourism to Scandinavia grew briskly over a 10 -year period from 2007. In Stockholm overnight stays grew by 50\%, in Oslo they increased by $55 \%$ while Iceland had a true tourist boom with a growth rate of $290 \%$.

Part of the growth in tourism has been accompanied by the rise of Airbnb. There is some research indicating that the activity level of Airbnb can have a significant effect on house and rental prices. Elíasson and Ragnarsson (2018) estimate that Airbnb rental activity in Reykjavik has led to an additional annual house price increase of $2 \%$, or 6 in total, over the period 2014-2017. Of all new apartment construction in Reykjavik in $2016,50-70 \%$ is estimated to be undertaken to replace houses that have been put up for rent on Airbnb and taken out of the long-term rental market.

The idea put forward in Elíasson and Ragnarsson is supported by qualitatively similar findings for other countries. Barron et al. (2018) estimate for the U.S. that in zip code areas with the median owner-occupancy rate (72\%), a $1 \%$ growth of Airbnb listings leads to a $0.018 \%$ rise in the rental rate and a $0.026 \%$ increase in house 
prices. ${ }^{3}$ A study for The Netherlands (ING Bank 2016) estimated that house prices in Amsterdam may have increased permanently by $2-4 \%$ because the rental income home owners collect can be used to obtain larger mortgages.

Other factors that may have contributed to an already upward trend in Scandinavia are a safe haven effect after the sovereign debt crisis, the low interest rates and a shift in credit standards. Sweden, for example, gradually moved from a system with unregulated but "conventional" downpayments and regular amortizations into a system without or with very low downpayments or amortizations. ${ }^{4}$

A sharp rise in house prices, possibly followed by a steep downturn, can lead to generational differences in wealth effects and can produce random winners and losers in housing markets. This eventually can have other unforeseen and undesirable side effects. A recent paper by Haughwout et al. (2018) shows how temporary shifts in lending standards are likely to be the driving force behind the fall in home ownerships among the young in the US since the financial crisis. Because of the recent rise in house prices, this has also led to young households missing out on wealth accumulation and future collateral for lending.

\section{Policy Options}

To address both the structural frictions in housing markets as well as the consequences of rapidly rising house prices, economic policymakers have several options available to them.

With respect to structural policies, Bergendahl et al. (2015) suggest that making large infrastructural investments conditional on beneficiary municipalities committing to local housing construction can mitigate the misalignment of incentives between different layers of government. Building permit processes, which are often slow and prone to lengthy appeals, can also be made more efficient. More flexibility can be introduced into the regulated rental market and the market for subletting, for example by allowing for longer periods of subletting or by incentivizing renters to move to the non-regulated sector when their income situation improves.

Structural policies are most likely to provide long-term solutions to structural changes, such as a change in housing demand. They can, however, also take years from decision to actual delivery and are therefore unlikely to alleviate frictions in the short or medium run. Fiscal and credit market policies can then complement structural policies by providing quicker relief to credit and housing markets.

\footnotetext{
${ }^{3}$ They also find that the effect of Airbnb listings on rental rates and house prices is decreasing in the owner-occupancy rate.

${ }^{4}$ Recently, an amortization policy was introduced that implies mandatory amortization for borrowers with a high LTV.
} 
On the fiscal side, tax incentives for households to assume debt can be lessened by limiting interest rate deductibility, while lock-in effects of capital gains taxes can be mitigated by allowing for a deferral of tax payments. Reducing interest rate deductibility does not, however, necessarily reduce the fragility of households or the affordability of housing, while it does lead to a complicated wealth transfer from older to younger generations. The prime advantage of a change in the fiscal treatment of mortgage debt is therefore likely to be that alternative investment forms receive a more equal treatment.

Credit market policies can be employed to protect consumers and financial institutions against excessive leverage and risk stemming from concentrated exposure to mortgage lending and housing collateral. Borrowing constraints, such as a debt-to-income ratio, and mandatory amortization can reduce indebtedness and the risk of a mortgage default. Loan-to-value (LTV) ratios can be used to limit the risk to banks if a default occurs. Typically, LTV's are less effective in restricting mortgage lending, unless they are allowed to vary over the cycle. Agarwal et al. (2014) show that counseling consumers about mortgage risks and alternatives can sometimes be an effective tool to mitigate mortgage risk and show evidence from a US policy experiment that led lower risk mortgage applicants to choose safer mortgage contracts.

\section{An Example of a Macroprudential Policy Measure}

Finally, we will provide some more details on a recently adopted macroprudential policy in Norway that generally restricted mortgage lending and imposed additional restrictions on lending in Oslo.

In 2015, as house prices in Oslo were rising at a rate of more than $10 \%$ per year, the Norwegian government imposed an 85\% LTV requirement (see Table 11.1). The LTV was accompanied by a $5 \%$ interest rate stress test requirement, implying that borrowers should be able to repay their loans if the interest rate rises by $5 \%$. A mandatory annual amortization of $2.5 \%$ for mortgages with an LTV over $70 \%$ was introduced as well. ${ }^{5}$ Each bank was allowed an exemption quota which permits a bank to grant loans that breach one or more of the policy requirements for up to $10 \%$ of its quarterly mortgage volume.

In January 2017 these requirements were tightened and complemented with a debt-to-income requirement (DTI) of five times gross income while amortization was made mandatory for mortgages with an LTV exceeding 60\%. For second dwellings in Oslo, which in principle are buy-to-let, the new policy set a stricter LTV of $60 \%$. For new mortgages with collateral in Oslo, the exemption quota was tightened to $8 \%$.

\footnotetext{
${ }^{5}$ In December 2011 the same rules were introduced as "Guidelines to prudent mortgage lending" by the Financial Supervisory Authority of Norway.
} 
Table 11.1 Mortgage restrictions in Norway 2015-2018

\begin{tabular}{l|l|l|l}
\hline Requirement & June 2015 & Jan 2017-June 2018 & July 2018-Dec 2019 \\
\hline Max. loan-to-value (LTV) & $85 \%$ & $85 \%$ & $85 \%$ \\
\hline $\begin{array}{l}\text { Debt servicing possible with } \\
\text { interest rate increase of }\end{array}$ & 5 p.p. & 5 p.p. & 5 p.p. \\
\hline $\begin{array}{l}\text { Maximum debt-to-income } \\
\text { (DTI) }\end{array}$ & $\begin{array}{l}\text { For LTVs } \\
\text { above 70\% }\end{array}$ & For LTVs above 60\% & For LTVs above 60\% \\
\hline $\begin{array}{l}\text { Compulsory principal } \\
\text { payment }\end{array}$ & $\begin{array}{l}\text { Max. LTV 60\% for } \\
\text { secondary dwellings } \\
\text { in Oslo }\end{array}$ & $\begin{array}{l}\text { Max. LTV 60\% for } \\
\text { secondary dwellings } \\
\text { in Oslo }\end{array}$ \\
\hline Regional requirements & $\begin{array}{l}10 \% \\
8 \% \text { in Oslo }\end{array}$ & $\begin{array}{l}10 \% \\
8 \% \text { in Oslo }\end{array}$ \\
\hline Exemption quota & & $\begin{array}{l}\text { Broader income and } \\
\text { wealth definitions, certain } \\
\text { exemptions on amortiza- } \\
\text { tion and debt-to-income } \\
\text { requirements for retirees }\end{array}$ \\
\hline Other exemptions & & & $5 \%$ pre-tax earnings \\
\hline
\end{tabular}

Time periods refer to the start and end period of policies. Source: Borchgrevink and Næss Torstensen (2018)

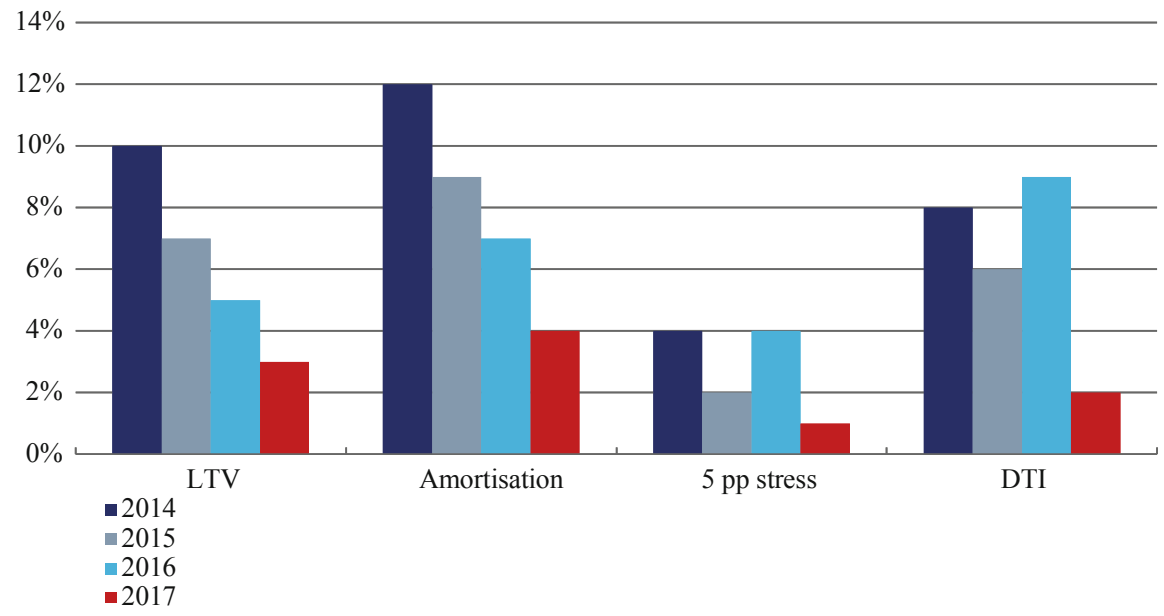

Source: Borchgrevink and Ncess Torstensen (2018)

Fig. 11.4 Mortgage policy breaches in Norway 2015-2018. For 2014-2016 we assume the 2017 mortgage policy already applied and calculate what share of all loans would have been in excess of each criterion

Figure 11.4 shows that the policy has had a substantial impact on the share of loans that exceed the DTI, fail the stress test requirement or do not amortize at the prescribed rate. The share of loans with a DTI in excess of five fell from $9 \%$ in 2016 to less than $2 \%$ in 2017 , less than $1 \%$ of mortgages failed the stress test in 2017 


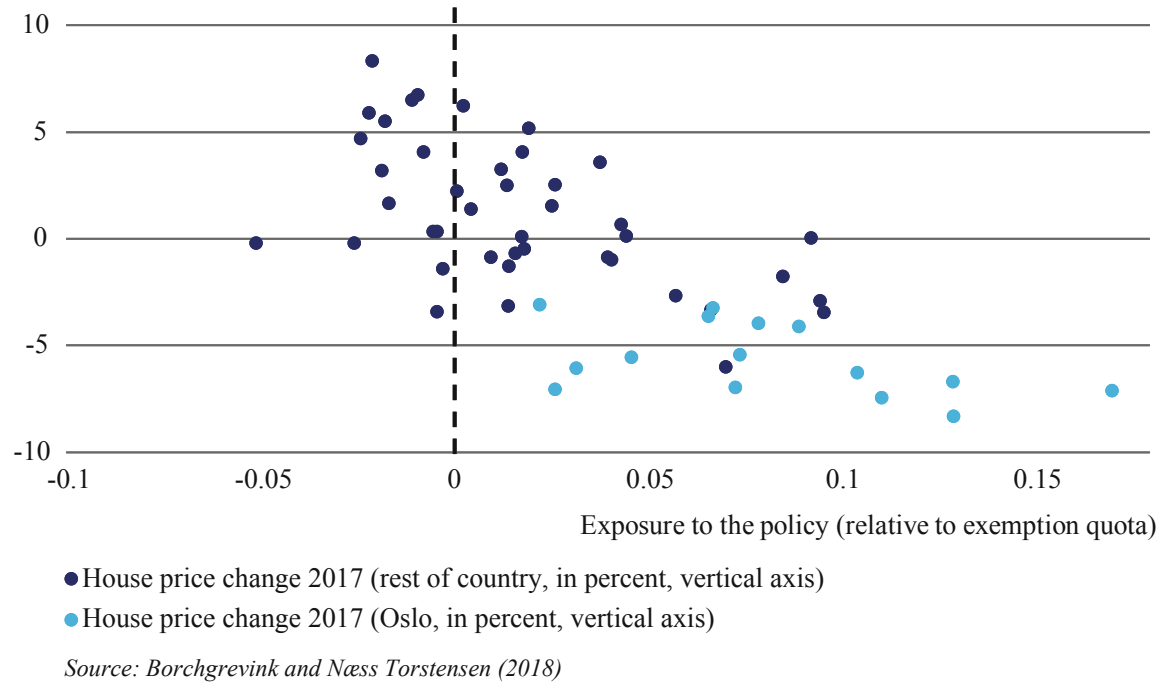

Fig. 11.5 House price changes and "exposure" to the DTI lending restriction. Exposure is measured as the percentage of households "with a DTI greater than five" that exceeds the exemption quota ("speed limit"). Blue dots are residential areas in greater Oslo, black dots are residential areas in the rest of the country

(2016: $4 \%$ ) and less than 4\% of mortgages with an LTV over $60 \%$ amortized at ate of below $2.5 \%$ (2016: $7 \%$ ). ${ }^{6}$ A more granular breakdown of the data shows that these effects have been strongest among younger borrowers.

Because the 2017 policy change appears to have been most binding with respect to the DTI, we have taken a closer look at how geographical variation in the exposure to the DTI constraint has affected house price development (Borchgrevink and Torstensen 2018). When we sort residential areas by the share of loans that was given in excess of the DTI policy in 2014, and subtract each area's local exemption quota, we see in Fig. 11.5 that a clear negative relation exists between the share of "high" DTI loans and the price development in 2016-2017. In 2017 house prices rose by $4.7 \%$ less in "exposed" areas than in non-exposed areas. When we control for "fundamental" differences between regions (unemployment, the supply of new houses et cetera), the size of the effects falls to $2.3 \%$. If we exclude municipalities in the Oslo area (the white dots), the effect falls to $1.7 \%$ but remains statistically significant.

At the same time house sales have not been affected in any greater way, except for people in the age range 20-24 as well as in Oslo, where the share of borrowers with a

\footnotetext{
${ }^{6}$ For 2016 we assume "hypothetical" breaches of the requirements, i.e., we assume the policy already applied, and calculated what share of all loans was in excess of these criteria in one or more dimensions.

${ }^{7}$ We classify an area as exposed if the share of loans with a DTI greater than five exceeded the exemption quota of that region (10\%, but $8 \%$ in Oslo).
} 
DTI greater than 5 had been high. We are also observing that the negative relation between the regional share of mortgages with a DTI above five and mortgage debt increases in 2017 has been particularly large for households in the age range 20-40.

These preliminary data show that the Norwegian mortgage policy likely dampened house price development and mortgage debt growth in regions with initially high debt levels and with more borrowers impacted by the policy. This could be indicative of a reduction in both riskier second house purchases and riskier lending/ borrowing.

On June 18, 2018, the government decided to extend the mortgage policy by another year and a half, until December $31,2019 .{ }^{8}$

\section{Conclusions}

Scandinavian capitals have grown fast and are projected to be among the fastest growing cities in Europe in the next decades. Rising house demand has not been matched by construction over a longer time period. Taxes, regulation and lack/ mismatch of incentives to build have been identified as the main frictions. Growth in tourism, low interest rates, a safe haven effect and credit "innovation" have likely contributed to house price rises. In markets with fewer frictions, leveraged investments have taken place in secondary housing for rent.

The mismatch between housing supply and demand can have several negative side effects, including unintended wealth transfers between generations. Structural policies are first best solutions to address mostly structural frictions. Macroprudential policies, such as a mortgage policy, can mitigate some of these side effects.

A more tempered growth rate of house prices can be beneficial to housing market entrants. Macroprudential policies can therefore complement structural policies. A preliminary assessment of a policy to restrict the demand for housing credit in Oslo displays signs of success.

Acknowledgements We would like to thank Paulina Tedesco and Marius Hagen (Norges Bank) as well as Kerstin Hallsten, Goran Katinic and Peter van Santen (Sveriges Riksbank) for their kind assistance.

\footnotetext{
${ }^{8}$ The government made a few adjustments to the mortgage regulations, by allowing banks to include documented and stable tax-free income, such as child allowance, in the calculation of the DTI and funds in a "tax deduction for young people's housing savings" (BSU) account as equity in calculating the LTV.
} 


\section{References}

Agarwal, S., Amromin, G., Ben-David, Z., Itzhak, S. C., \& Evanoff, D. (2014). The effectiveness of mandatory mortgage counseling: Can one dissuade borrowers from choosing risky mortgages? www.ssrn.com/abstract $=1285603$

Barron, K., Kung, E., \& Proserpio, D. (2018). The sharing economy and housing affordability: Evidence from Airbnb. https://ssrn.com/abstract $=3006832$

Bergendahl, P.-A., Löfmark, M. H., \& Lind, H. (2015). Bostadsmarknaden och den ekonomiska utvecklingen. Appendix 3 to Långtidsutredningen 2015. Official Reports of the Swedish Government 2015:48.

Borchgrevink, H., \& Torstensen, K. N. (2018). Analyser av effekter av boliglånsforskriften [Analyses of Effects of Mortgage Regulation]. Economic Commentary Norges Bank 2018:1.

Elíasson, L., \& Ragnarsson, Ö. P. (2018). Short-term renting of residential apartments: Effects of Airbnb in the Icelandic housing market. Working paper Central Bank of Iceland 2018:76.

European Commission. (2015). Population projections. Accessed May 2018, from https://ec. europa.eu/eurostat/web/population-demography-migration-projections/population-projectionsdata

Haughwout, A., Lee, D., Scally, J., \& van der Klaauw, W. (2018). Home prices, housing wealth and home equity extraction. New York: Federal Reserve Bank of New York.

ING Bank. (2016, April 25). Airbnb heeft flink opwaarts effect op Amsterdamse huizenprijzen [Airbnb has a significant upward effect on Amsterdam house prices]. https://www.ing.nl/ nieuws/nieuws_en_persberichten/2016/04/airbnb_heeft_flink_opwaarts_effect_op_ amsterdamse_huizenprijzen.htm

Katinic, G. (2018). Perspectives on housing construction. Economic commentary 2018:2. Sveriges Riksbank.

Norges Bank. (2017). Financial stability report.

Nygaard, R. (2013). Rent levels in the Norwegian rental market. Memo Statistics Norway.

Sveriges Riksbank. (2017). Financial stability report 2017:2.

Open Access This chapter is licensed under the terms of the Creative Commons Attribution 4.0 International License (http://creativecommons.org/licenses/by/4.0/), which permits use, sharing, adaptation, distribution and reproduction in any medium or format, as long as you give appropriate credit to the original author(s) and the source, provide a link to the Creative Commons licence and indicate if changes were made.

The images or other third party material in this chapter are included in the chapter's Creative Commons licence, unless indicated otherwise in a credit line to the material. If material is not included in the chapter's Creative Commons licence and your intended use is not permitted by statutory regulation or exceeds the permitted use, you will need to obtain permission directly from the copyright holder.

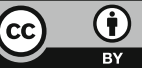

